This PDF is a selection from a published volume from the National Bureau of Economic Research

Volume Title: Growth and Productivity in East Asia, NBER-East Asia Seminar on Economics, Volume 13

Volume Author/Editor: Takatoshi Ito and Andrew K. Rose, editors

Volume Publisher: University of Chicago Press

Volume ISBN: 0-226-38680-5

Volume URL: http://www.nber.org/books/ito_04-2

Conference Date: June 20-22, 2002

Publication Date: June 2004

Title: Australia's 1990s Productivity Surge and Its Determinants Author: Dean Parham

URL: http://www.nber.org/chapters/c10744 


\section{Australia's 1990s Productivity Surge and Its Determinants}

Dean Parham

\subsection{Introduction}

Australia's growth performance since the early 1990s has been exceptional. Over the last ten years, annual gross domestic product (GDP) growth averaged just under 4 percent - a performance not seen since the 1960s and early 1970s. Strong growth even persisted in the midst of the 1997 Asian financial crisis and the 2001 global downturn.

A surge in productivity growth has underpinned Australia's good performance. After showing its weakest rate in the 1980s, Australia's productivity growth accelerated by a little over 1 percentage point to new highs in the 1990 s - labor productivity growth at an average 3.2 percent a year and multifactor productivity (MFP) growth at 1.8 percent a year.

The much-improved performance has stimulated a search for reasons. A few commentators have disputed the significance of the evidence of a productivity surge by speculating about the influence of recovery from the early 1990 s recession and measurement error. ${ }^{1}$ But the length and strength

Dean Parham is assistant commissioner at the Productivity Commission, Australia.

This paper partly draws on and updates previous work undertaken with colleagues Paul Roberts and Haishun Sun (Parham, Roberts, and Sun 2001). Paula Barnes, Paul Roberts, and Tracey Horsfall assisted with the preparation of the paper. Richard Snape made comments on a previous draft. Helpful comments from discussants at the seminar and the editors and referees of the volume of proceedings are gratefully acknowledged. Any remaining errors are mine. The views expressed do not necessarily reflect the views of the Productivity Commission.

1. To account for an acceleration in productivity growth any measurement error would have to have worsened (if an overestimation) or diminished (if an underestimation). The latter is more possible in that estimation of productivity in some service industries may have improved. On the other hand, many OECD countries have similarly improved and harmonized aspects of estimation, without generating estimates of productivity acceleration anywhere near the strength of Australia's. 
of the productivity resurgence-controlling for cyclical influences-demand some "structural" explanations. Most attention has focused on three candidates:

- a shift in the production frontier due to the introduction of new technology - specifically information and communications technologies (ICTs);

- a shift toward the frontier through efficiency improvements stimulated by a set of microeconomic policy reforms - "catch-up" gains from firms moving toward best practice and from resources shifting to where they can be used more productively;

- an increase in average education attainment and skills that would increase human capital deepening and promote productivity through the absorption and development of technologies and efficient business practices.

This paper concentrates on the first possible explanation, particularly since there has been worldwide interest in ICTs as a source of productivity growth. A comparison with U.S. experience, using a growth accounting framework, provides the basis for assessing the contribution of ICTs to Australia's aggregate productivity acceleration. Productivity growth and the ICT contributions to it are sensitive to cyclical effects. This study is distinguished from others by the attention paid to selection of periods that minimize cyclical effects. The paper also draws on other empirical work to briefly assess other possible explanations.

\subsection{An Overview of Australia's Productivity Performance}

Australia's recent productivity performance needs to be set in a broad historical and international context to highlight some of the developments that should be covered in a comprehensive explanation of the 1990s surge.

\subsubsection{A Broad Sweep across Countries and the Decades}

Australia's rate of productivity growth was comparatively low over most of the twentieth century. At the beginning of the century, Australia had one of the highest levels of labor productivity in the world (Maddison 2001), reflecting a relative abundance of natural resources per hour worked. Governments subsequently traded this high productivity position for nation building as, with widespread popular support, they encouraged population growth, diversification of the economic base, and redistribution of income through a set of policies that (perhaps unintentionally) held growth in productivity in check.

Nevertheless, Australia still enjoyed a relatively high ranking at the start of the postwar era. In 1950, Australia's GDP per hour was 81 percent of 


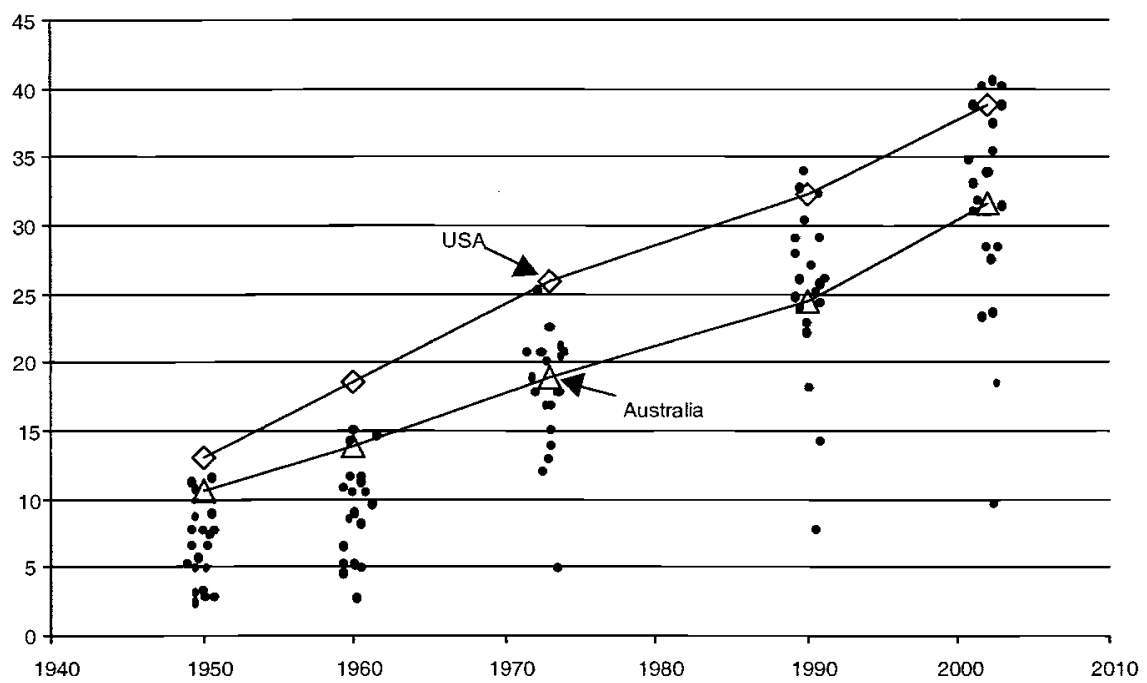

Fig. 2.1 Labor productivity in OECD countries, 1950, 1960, 1973, 1990, and 2001: GDP per hour (US\$ at purchasing power parity)

Source: Data from University of Groningen and The Conference Board, GGDC Total Economy Database, 2003; http://www.eco.rug.nl/ggdc, accessed 25 July 2003.

the productivity leader - the United States - and it ranked fourth among a group of twenty-two developed or high-income countries (figure $2.1^{2}$ and table 2.1).

The next four decades were a period of catch-up to the leader and convergence in productivity levels. European countries, in particular, started to catch up and in some cases overtook the United States (figure 2.1).

Australia did not participate in this "convergence club." Many countries also overtook Australia as it slipped further behind the United States in the 1950 s and then merely maintained its position relative to the United States until 1990. Australia's ranking slipped to sixteen by 1990 .

A string of policy reviews in the 1960s, 1970s, and 1980s attributed this relatively poor performance to highly regulated product, capital, and labor markets and the inefficient provision of economic infrastructure (energy, water, transport, communications), which was dominated by governmentowned enterprises operating without clear commercial imperative or performance regulation.

As a consequence of relatively poor productivity growth, Australia's ranking on the international league table of GDP per capita also droppedfrom five in 1950 to sixteen in 1990 (table 2.1).

2. Figure 2.1 shows productivity levels in twenty-two OECD countries in 1950, 1960, 1973, 1990, and 2001. Some observations are offset from the reference year on the chart to avoid overwriting. 
Table 2.1

Australia's Rankings on Productivity, Average Income, and Labor

Utilization Levels among Twenty-Two OECD Countries

\begin{tabular}{lrrrrr}
\hline & 1950 & 1960 & 1973 & 1990 & 2002 \\
\hline GDP per hour & & & & & \\
$\quad \begin{array}{l}\text { Australia's rank } \\
\text { \% of U.S. level }\end{array}$ & 81 & 75 & 73 & 76 & 83 \\
$\begin{array}{l}\text { GDP per capita } \\
\quad \begin{array}{l}\text { Australia's rank } \\
\text { \% of U.S. level }\end{array}\end{array}$ & 5 & 8 & 10 & 16 & 8 \\
Labor utilization & 78 & 78 & 76 & 73 & 78 \\
$\quad \begin{array}{l}\text { Australia's rank } \\
\text { \% of U.S. level }\end{array}$ & 15 & 16 & 6 & 6 & 7 \\
\hline
\end{tabular}

Source: See figure 2.1.

Note: Labor utilization is the number of hours worked per head of total population. It explains the difference between GDP per hour and GDP per capita.

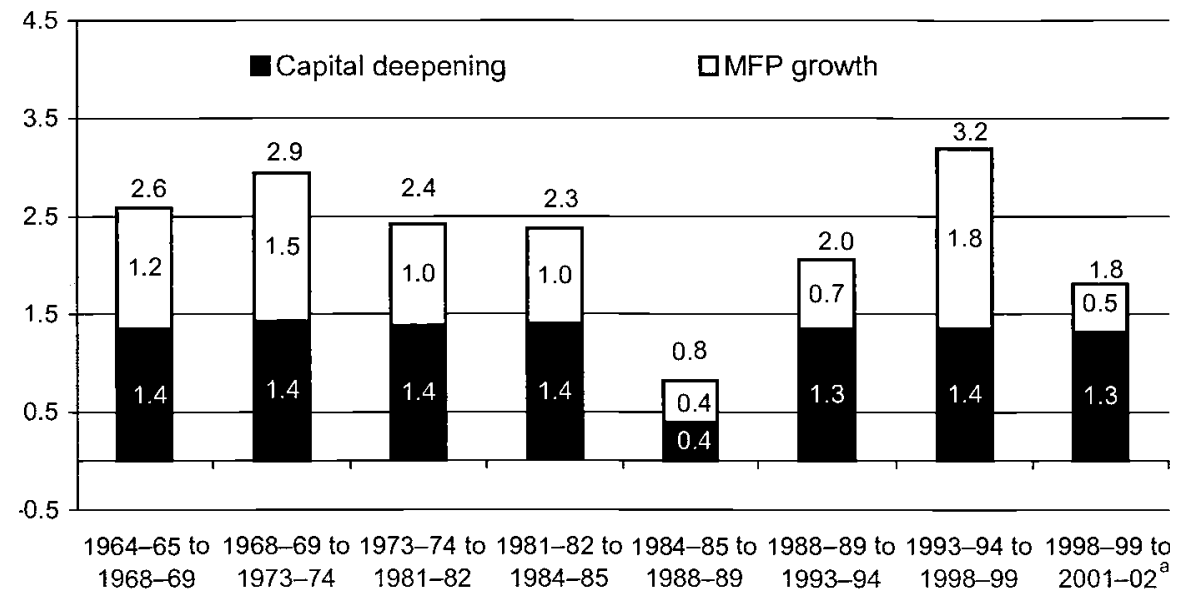

Fig. 2.2 Growth in labor productivity over productivity cycles and contributions from capital deepening and multifactor productivity, 1964-65 to 2001-02: average annual rates of growth (percent)

Source: Australian Bureau of Statistics (ABS) 5204.0 and Productivity Commission estimates.

Note: Productivity cycles are the intervals between productivity peaks, as identified by the ABS.

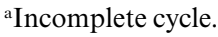

\subsubsection{The Productivity Surge in the 1990s}

Figure 2.2 shows the rates of labor productivity growth over productivity cycles in the market sector of the Australian economy. Measurement over productivity cycles - from productivity peak to productivity peak - neutralizes the spurious influence of the business cycle. The latest period, 1998-99 to 2001-02, is not a complete cycle. Since productivity growth over this period cannot be taken confidently to be an underlying 


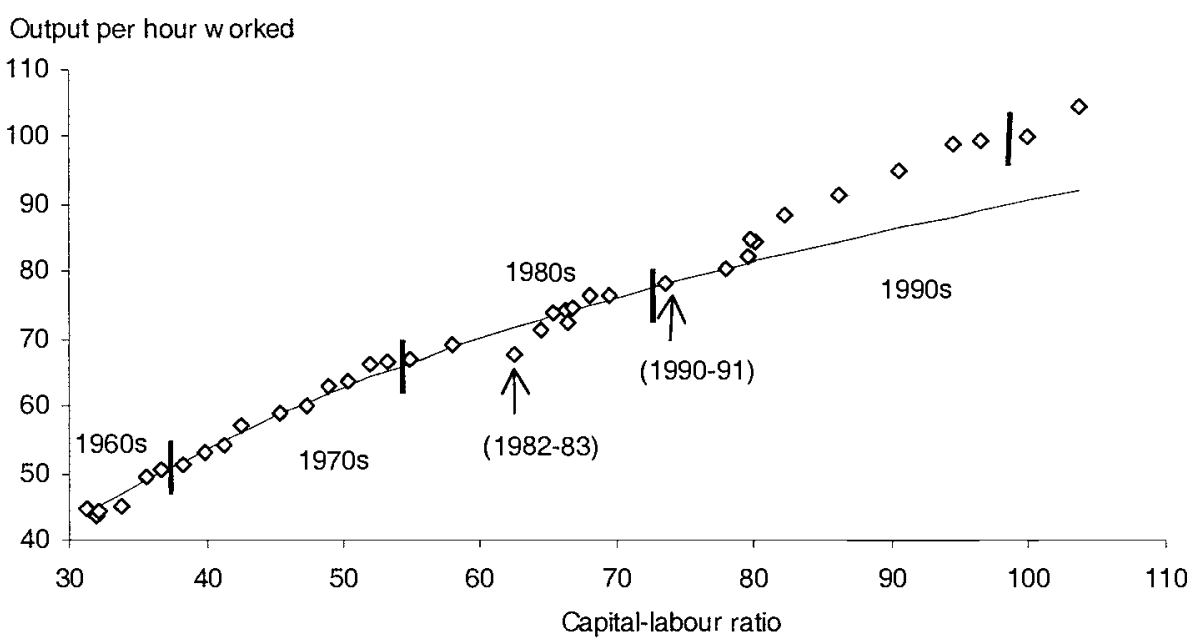

Fig. 2.3 Australia's growth path, 1964-65 to 2001-02 (indexes 2001-01 = 100) Source: ABS 5204.0.

Note: The years in brackets correspond to troughs in the business cycle.

rate, attention is focused on the most recent completed cycle, 1993-94 to 1998-99.

The figure shows that Australia's productivity growth rebounded in the 1990s, with underlying rates reaching record highs. The record 3.2 percent annual average labor productivity growth in the 1993-94 to 1998-99 cycle compares with an average of 2.0 percent in the previous cycle and 1.7 percent over the cycles from 1981-82 to 1993-94.

MFP growth was the major contributor to improved labor productivity growth. With the rate of capital deepening stable at around 1.4 percent a year, better MFP growth has accounted for all of the acceleration in Australia's underlying labor productivity growth (fig. 2.2). Record MFP growth of 1.8 percent a year accounted for around two-thirds of labor productivity growth in the 1990 s cycle. MFP accelerated from 0.7 percent a year - the average over both the previous cycle and the three cycles between 1981-82 and 1993-94.

The start of the surge cannot be pinpointed with precision because of recession-related effects. Figure 2.3 suggests that the Australian economy took a new growth path, based on higher MFP growth, in the early 1990s, by 1993. ${ }^{3}$ Even without precision, it would appear that Australia's

3. Figure 2.3 plots paired observations of the capital-labor ratio and labor productivity levels. Because of the general tendency of capital deepening, the observations line up in chronological order. Shifts from one observation to another can be attributed to combinations of capital deepening and MFP growth. If the relative importance of MFP growth increases, as happened in the 1990s, the observations follow a steeper gradient. See Parham (1999) for more details on growth path analysis. 


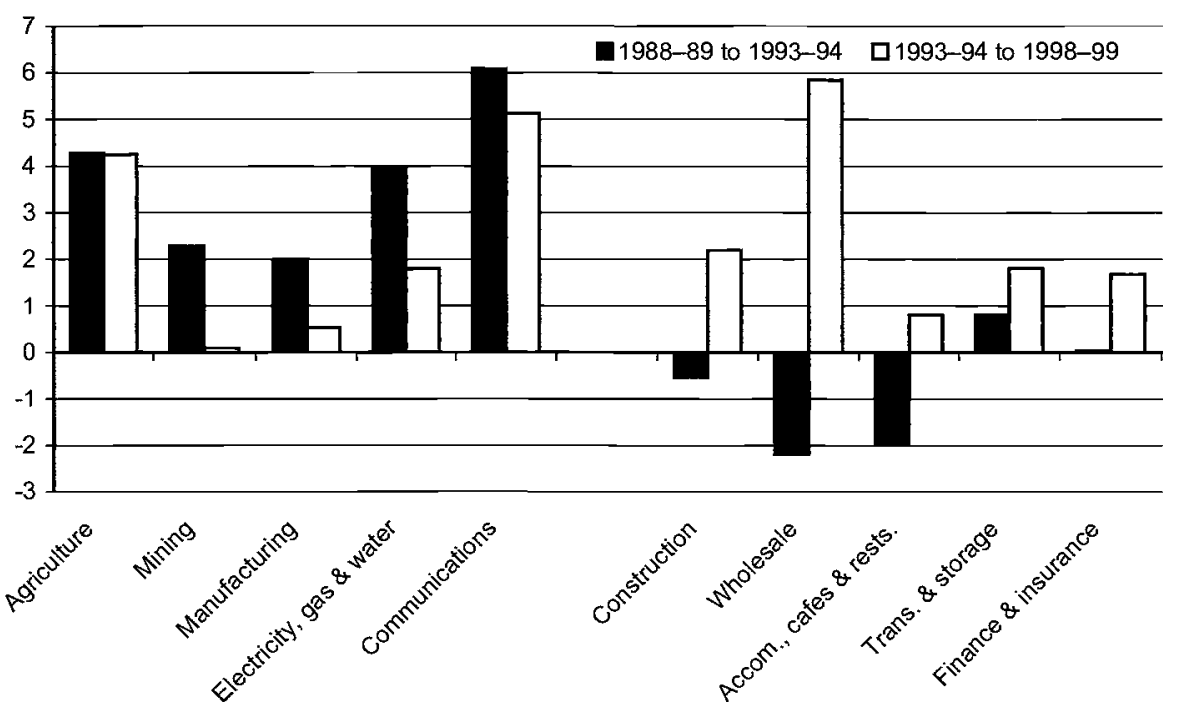

Fig. 2.4 MFP growth in selected industries over the last two aggregate productivity cycles: average annual rates of growth (percent)

Source: Productivity Commission estimates based on unpublished ABS data.

productivity surge predated the uplift in U.S. productivity growth from 1995.

Strong productivity growth in the 1990s fuelled relatively strong growth in average incomes and raised Australia's GDP per capita ranking to 8 by 2002 (table 2.1). Australia's level of GDP per head had recovered from 73 percent of the U.S. level in 1990 to regain its very long-term position at around 78 percent by 2001 .

In summary, Australia's productivity and average income growth were relatively poor when there was a worldwide productivity boom in the catchup and convergence era of the postwar period. Australia only started to catch up on the United States during the 1990s - a period of mixed performance across countries. U.S. productivity accelerated, contributing to a breakdown in convergence across OECD countries. ${ }^{4}$ Australia not only kept pace with, but exceeded, the U.S. acceleration to record one of the highest accelerations in the Organization for Economic Cooperation and Development (OECD) area (OECD 2001a).

The 1990s brought an important change in the industry sources of aggregate productivity growth. Figure 2.4 presents MFP growth rates in industry sectors over the past two aggregate productivity cycles. Some cau-

4. Catch-up and convergence stalled in the 1990s as U.S. productivity accelerated relative to most other countries (Australia being one notable exception). Convergence actually broke down in the second half of the 1990s, when the U.S. productivity acceleration was strongest (OECD 2001a; McGuckin and van Ark 2002). 
tion about the precision of industry estimates is appropriate, particularly in view of the value added method of estimation, which has been used in the absence of data to support a KLEMS approach. ${ }^{5}$

In the 1988-89 to 1993-94 cycle, there was relatively strong productivity growth in the "traditional" contributors to aggregate productivity growth - agriculture, mining, and manufacturing (left-hand side of fig. 2.4). Two other strong performers - communication services and electricity, gas, and water-joined these traditional sectors in this cycle. Their improved performance stemmed from the major efficiencies (e.g., better investment decisions and reductions in excess manning) achieved in government enterprises, as well as technological advances in some activities.

While productivity growth remained relatively strong in most of these industries in the 1990s cycle (mining and manufacturing being exceptions), all these industries experienced a deceleration compared with the previous cycle. On these estimates, none made a contribution to the productivity surge from 1993-94.

A new set of service industries emerged in the 1990s. The standout performer was wholesale trade. Other service industries-for example, construction and finance and insurance - also increased their rate of productivity growth significantly. Because of their relative size, wholesale trade, construction, and finance and insurance made the most substantial contributions to the aggregate acceleration (table 2.2).

\subsubsection{Key Features of the Productivity Surge}

This sketch of Australia's productivity performance has highlighted the following key developments that need to be explained:

- From an international perspective, Australia's productivity growth switched from being relatively slow over at least four decades to become relatively fast in the 1990s.

- The acceleration in labor productivity growth came through improved efficiency (MFP growth) rather than increased capital deepening.

- The 1990s surge in MFP growth originated in a new set of service industries, in particular wholesale trade, construction, and finance and insurance.

The absence of a worldwide productivity boom, the relative strength of Australia's productivity acceleration, and its starting point in the early 1990s suggest that some specifically Australian factors must form at least an important part of the explanation.

The contribution of ICTs is now assessed. There was an ICT boom in the 1990s in a number of countries, including Australia.

5. The differences in value added and KLEMS approaches are discussed by, for example, Gullickson and Harper (1999). 
Table 2.2

Industry Contributions to the Acceleration in Market-Sector Multifactor Productivity (MFP)

\begin{tabular}{lccc}
\hline & $\begin{array}{c}\text { MFP Acceleration } \\
\text { (\% per annum) }\end{array}$ & $\begin{array}{c}\text { Output } \\
\text { Share }(\%)\end{array}$ & $\begin{array}{c}\text { Contribution } \\
\text { (percentage points) }\end{array}$ \\
\hline Agriculture & 0.0 & 6 & 0.0 \\
Mining & -2.2 & 8 & -0.3 \\
Manufacturing & -1.5 & 22 & -0.5 \\
Electricity, gas, and water & -2.2 & 5 & -0.2 \\
Construction & 2.7 & 9 & 0.4 \\
Wholesale trade & 8.0 & 9 & 1.1 \\
Retail trade & 0.7 & 9 & 0.1 \\
Accommodation, cafes, and & & 3 & 0.1 \\
$\quad$ restaurants & 2.8 & 9 & 0.1 \\
Transport and storage & 1.0 & 5 & -0.1 \\
Communications & -1.0 & 11 & 0.3 \\
Finance and insurance & 1.7 & 3 & -0.1 \\
Cultural and recreational & & & 1.1 \\
$\quad$ services & -1.7 & 100 & \\
Market sector & 1.1 & &
\end{tabular}

Source: Productivity Commission estimates based on ABS data.

Notes: MFP acceleration is the change in growth from the period 1988-89 to 1993-94 to the period 1993-94 to 1998-99. Output shares are calculated from estimates of current price value added for 1993-94.

\subsection{The Role of ICTs in Australia's Productivity Surge}

Many consider ICTs to be the major productivity-enhancing technological advance of the 1990s. Advances in ICTs have brought widespread and, in some cases, quite fundamental changes to businesses and households. ICTs have been linked to labor productivity growth through three avenues.

Increases in capital deepening. Labor productivity can rise as a result of higher capital use per unit of labor, as firms invest in more ICTs (where measurement of ICT volumes takes into account increases in quality). Many analysts have noted this mechanism affords ICTs no special qualities. As they have become cheaper, firms have substituted ICTs for labor and other forms of capital - as could happen for many other inputs.

Productivity gains in ICT production. Producers' ability to manufacture much more powerful ICT equipment, with relatively little increase in inputs, generates substantial MFP gains. If the gains are of sufficient magnitude and production is on sufficient scale, they can show up as contributions to aggregate MFP growth.

Productivity gains in ICT-using industries. This is the more controversial source of ICT-related productivity gains. It requires that use of ICTs generate MFP gains. On the one hand, "new economy" enthusiasts have pointed to MFP gains from such sources as increasing returns from ICT use and spillovers from network economies. On the other hand, skeptics 
have either denied or found little evidence to support the existence of MFP gains from use.

Australia cannot access productivity gains from ICT production. The ICT equipment production sector is not of sufficient size to generate productivity gains of national significance.

However, Australia has become a high ICT user. In 2000, Australia ranked third (behind the United States and Finland) among OECD countries on expenditure on ICTs as a proportion of non-residential investment - a marked step up from its 1980 ranking (OECD 2002). Investment in ICTs became a sizable proportion of total investment in Australia from the mid-1980s. Since then, the growth of investment has been very strong, especially in the second half of the 1990s, when investment in hardware grew by 35 percent a year and software investment by 20 percent a year in real terms.

As an importer of ICTs, Australia has benefited from a sizable terms-oftrade gain through the rapidly declining prices of ICTs. Strong international competition has meant that MFP gains in production have been passed on to purchasers. The Australian Treasury (Treasury 2002) stated that ICT prices have fallen in domestic currency terms by 9.5 percent a year and raised the terms of trade by 0.3 percent a year between 1985 and 2001. Since 1995, ICT prices have fallen by nearly 15 percent a year and raised the terms of trade by 0.75 percent a year.

\subsubsection{Aggregate Growth Accounting ${ }^{6}$}

A conventional productivity growth accounting exercise is now used to assess the influence of ICTs on Australia's productivity performance. A comparison with the United States is used to infer the likely contribution of ICTs to Australia's aggregate productivity growth.

The estimates of Australian labor productivity growth and the growth accounting contribution to it are based on national accounts data constructed by the Australian Bureau of Statistics (ABS). In keeping with modern practice, the ABS uses hedonic (or constant-quality) price deflators to estimate real volumes of ICTs produced and purchased. Hedonic prices have not been specifically generated for Australia. The ABS uses the U.S. price deflator for hardware, adjusted for exchange rate movements and a time lag, and a price deflator for software that shows a nominal 6 percent a year decline. The U.S. and Australian deflators are shown in figure 2.5.

There has been a string of U.S. studies of ICT contributions to productivity growth. For brevity, however, this paper focuses on comparisons with the United States, based on Bureau of Labor Statistics (BLS) data. Using BLS data brings two advantages:

6. The growth accounting presented in this section is updated from Parham, Roberts, and Sun (2001). 
Hardware

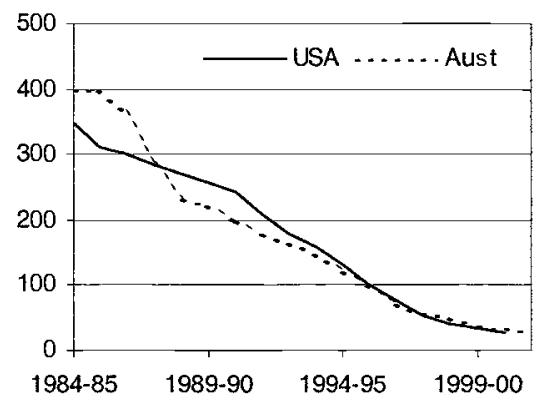

Software

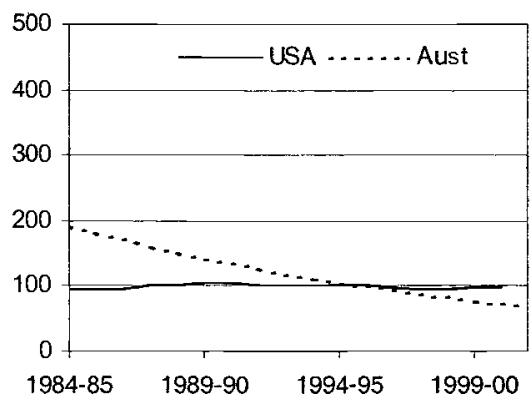

Fig. 2.5 ICT hardware and software price indexes, United States and Australia (index 1995-96 = 100)

Source: Unpublished ABS data and Bureau of Labor Statistics (BLS) data.

- The ABS models its methods closely on BLS methods, and this enhances comparability. ${ }^{7}$

- Access to the BLS data set assists flexibility in choosing periods for comparison.

A capital services measure of capital input is used and labor input is measured by hours worked. U.S. studies also include a labor composition or "quality" component, but this component cannot be estimated on a comparable basis or for the entire period for Australia. Consequently, this component is added back into the U.S. MFP growth estimates presented hereafter to assist comparability with Australian estimates. ${ }^{8}$

There was a big step up in contributions from ICT capital deepening from 1995 in the United States and Australia (fig. 2.6). The timing and strength of the ICT capital-deepening contributions in the two countries are remarkably close. This suggests that there have been similar rates of increase in ICT use in the two countries and supports the validity of using the United States as a comparator for the assessment of the impacts of ICT use in Australia.

Our work at the Productivity Commission has paid particular attention to selection of periods that identify underlying rates of productivity

7. Nevertheless, there are a few differences of note. Australian data cover information technology (IT), without communications equipment, whereas U.S. data cover ICTs. The U.S. estimates used here cover the private business sector, whereas Australian estimates cover the market sector. The main difference between the two is that the ABS-defined market sector excludes property and business services.

8. This does, of course, assist comparability, but in a conceptually inferior way. It would be preferable to factor out labor composition effects in Australia in order to draw comparisons with the United States. The practical significance of this issue rests on whether compositional effects would have been greatly different in the two countries. Unpublished ABS work (see section 2.4.1) suggests that compositional effects in Australia over the 1980s and 1990s would not be greatly dissimilar to those in the United States. 


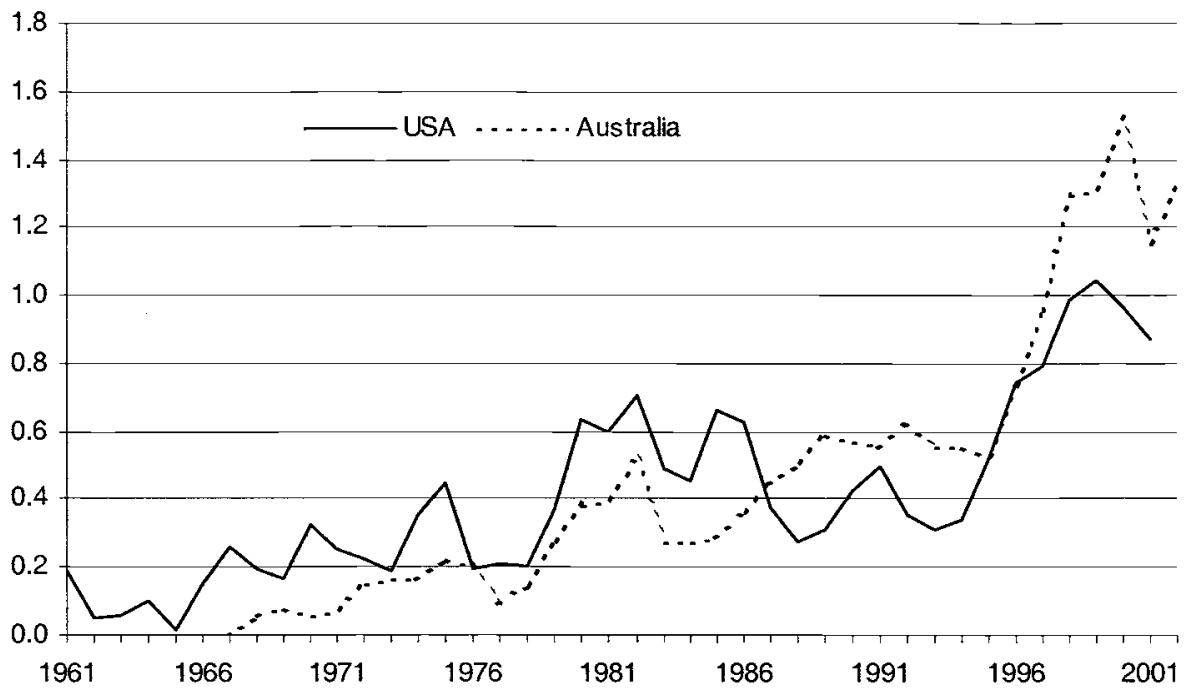

Fig. 2.6 Contributions of ICT capital deepening to labor productivity growth in the United States and Australia, 1961 to 2002 (percentage points)

Source: Productivity Commission estimates based on unpublished ABS data (to 2001-02) and BLS data (to 2001).

Note: For Australia, years refer to twelve months ending 30 June.

growth. Focus on underlying trends, rather than pre- and post-1995 rates of growth, presents a departure from nearly all other previous Australian and U.S. studies.

It is not surprising that most studies have used 1995 as the dividing year between periods for comparison of productivity growth and ICT contributions to it - for example, accounting for productivity growth in the second half of the 1990s (1995-99) compared with the first half (1990-95). ${ }^{9}$ The 1995 year corresponds to the takeoff point in more rapid advances in ICT technology, declines in ICT prices, growth in investment in ICTs, and, as just seen, growth in ICT capital deepening. Using 1995 as a break point between periods therefore highlights the ICT takeoff and its effects.

But using 1995 as the break point creates problems in identifying and accounting for underlying rates of productivity growth. U.S. labor productivity was in a trough in 1995, at a point below trend (fig. 2.7). ${ }^{10}$ Esti-

9. Major examples of studies using pre- and post-1995 periods are Oliner and Sichel (2000), Gordon (2000), Jorgenson and Stiroh (2000), and CEA (2001). Gordon, however, does make a cyclical adjustment. Simon and Wardrop (2001) is an Australian example.

10. A Hodrick-Prescott filter is used to form the trend series presented in figure 2.7. This does not clearly identify the Australian peaks as being above trend. However, the ABS uses an eleven-period Henderson moving average to identify a trend series and (the same) productivity peaks in official productivity estimates. 
United States

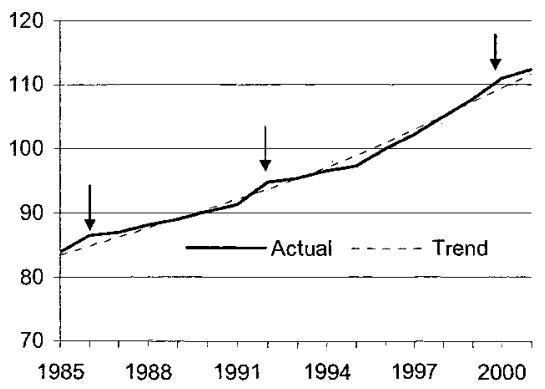

Australia

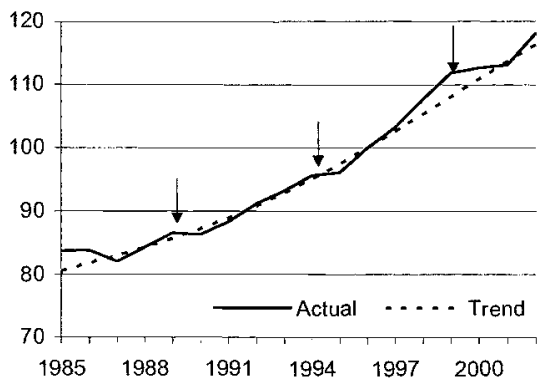

Fig. 2.7 Identifying peaks in U.S. and Australian labor productivity (index 1996 = 100)

Source: Unpublished ABS data (to 2001-02) and BLS data (to 2001).

Note: For Australia, years refer to twelve months ending 30 June.

mates of average growth from 1995 to the end of the 1990s are from a trough to a peak and therefore overstate the underlying rate of labor productivity growth. Moreover, the size of the estimated labor productivity acceleration is quite sensitive to minor variations in period selection around 1995 (Parham, Roberts, and Sun 2001).

Issues with the break point and sensitivity can be set aside by analyzing contributions to trend rates of productivity growth. The ABS method of estimating productivity growth over productivity cycles - from productivity peak to productivity peak - is one way of measuring underlying rates of growth. Adopting this method puts the prime focus on accelerations in underlying rates of productivity growth.

The contributions to labor productivity growth over productivity cycles are shown for the United States in figure 2.8 and for Australia in figure 2.9. The 1990s cycle for the United States is from 1992 to 2000 and for Australia from 1993-94 to 1998-99. Contributions to the labor productivity accelerations in the 1990s cycle (compared with the previous cycle) in both countries are presented in table 2.3. Contributions to the labor productivity accelerations from the first to the second half of the 1990s are shown for purely comparative purposes in table 2.4 . The estimated labor productivity acceleration is lower according to the productivity cycle method, compared with the pre- and post-1995 method. In particular, the U.S. acceleration is still significant but a much less spectacular 0.5 of a percentage point (table 2.3), compared with 1.1 percentage points (table 2.4).

There are several important similarities in the U.S. and Australian results:

- The ICTs have made strong capital-deepening contributions. The ICT capital-deepening contribution has increased steadily from the 1960s 


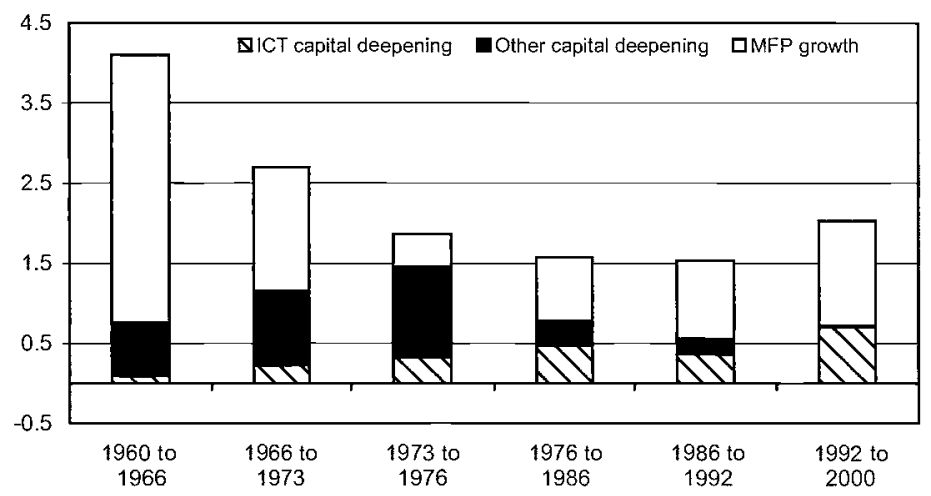

Fig. 2.8 Contributions to U.S. labor productivity growth over productivity cycles, 1960 to 2000 (percent per year)

Source: Productivity Commission estimates based on BLS data.

Note: MFP growth includes the labor composition (quality) contribution.

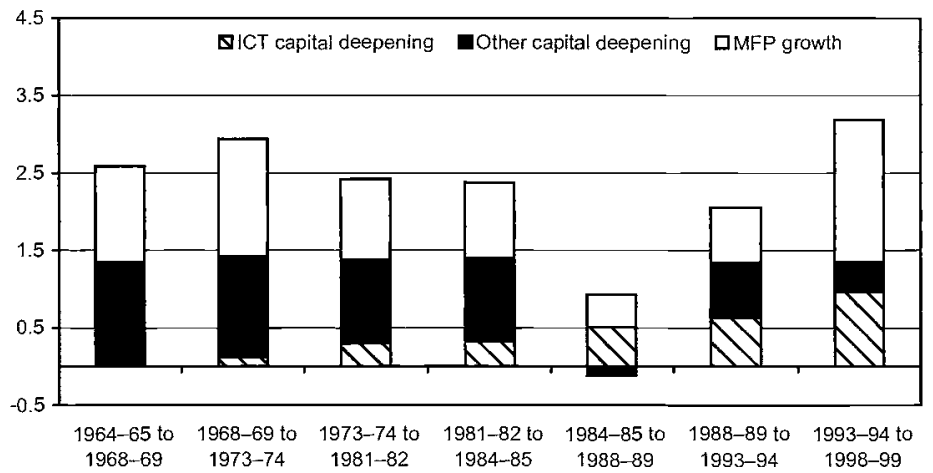

Fig. 2.9 Contributions to Australian labor productivity growth over productivity cycles, 1964-65 to 1998-99 (percent per year)

Source: Productivity Commission estimates based on unpublished ABS data.

in both countries (figs. 2.8 and 2.9). ICT capital deepening accounted for around a third of labor productivity growth in both countries in their respective 1990s cycles. ICT capital deepening made the same contribution ( 0.3 of a percentage point) to the 1990 s labor productivity accelerations in both countries (table 2.3 ). ${ }^{11}$

- However, there has been little or no increase in the overall rate of capital deepening in either country, especially in Australia (table 2.3). Much or all of the increased use of ICTs (per hour worked) in the

11. The slightly lower contribution in the United States was due to stronger labor input growth rather than weaker ICT capital growth. 
Table 2.3 Contributions to Labor Productivity Accelerations in the 1990s Productivity Cycle in the United States and Australia (percentage points)

\begin{tabular}{ccc}
\hline & United States & Australia \\
\hline Labor productivity acceleration & 0.5 & 1.2 \\
Capital deepening & 0.2 & 0.0 \\
ICT capital & 0.3 & 0.3 \\
Hardware & 0.3 & 0.4 \\
Software & 0.1 & -0.1 \\
Other & 0.0 & -0.3 \\
Other capital & -0.2 & 1.1 \\
MFP contribution & 0.3 & \\
\hline
\end{tabular}

Notes: United States column shows growth in 1992 to 2000 less growth in 1986 to 1992. Australia column shows growth in 1993-94 to 1998-99 less growth in 1988-89 to 1993-94.

Table 2.4

Contributions to Productivity Accelerations from 1990-95 to 1995-2000 in the United States and Australia (percentage points)

\begin{tabular}{lcc}
\hline & United States & Australia \\
\hline Labor productivity acceleration & 1.1 & 1.1 \\
Capital-deepening contribution & 0.6 & 0.4 \\
ICT & 0.5 & 0.5 \\
Other & 0.1 & -0.1 \\
MFP contribution & 0.5 & 0.6 \\
\hline
\end{tabular}

Note: For Australia, years refer to twelve months ending 30 June.

1990s has been offset by slower growth in use of other forms of capital (per hour worked). This result contrasts with that found in most other studies of the United States (exemplified by the results in table 2.4), which have found that ICTs have contributed to a marked increase in the rate of substitution of capital for labor.

- Growth in MFP accounted for over half the labor productivity growth in the 1990s cycle in both countries. Faster MFP growth accounts for most of the 1990s labor productivity accelerations in both countriesentirely so in Australia's case.

The main difference between the U.S. and Australian results lies in the strength of the productivity accelerations. The acceleration in underlying labor productivity growth in Australia, at 1.2 percentage points, is more than twice that in the United States (table 2.2). With similar capitaldeepening contributions, the chief explanation for the difference lies in the much stronger MFP acceleration in Australia (1.1 percentage points) than in the United States ( 0.3 of a percentage point).

The stronger productivity acceleration in Australia suggests that the 
Australian economy benefited from one or both of two factors: bigger gains from the use of ICTs and/or more gains from non-ICT factors. In either case, it does not necessarily mean - and generally it is highly unlikely - that productivity levels in Australia have moved ahead of U.S. levels. Rather, as the background in section 2.2 suggests, it is likely that Australia had more scope to improve from a lower base and has caught up on at least some of the superior U.S. levels.

It seems reasonable to assume, consistent with the U.S. leadership in productivity and ICTs, that the U.S. estimates establish the upper limit of 0.3 of a percentage point on the productivity acceleration that can be associated specifically with ICT production and use. ${ }^{12}$ Studies such as that by Oliner and Sichel (2000) have attributed around 0.3 of a percentage point of aggregate MFP growth acceleration to ICT production, although the acceleration was calculated pre- and post-1995 and may therefore overstate the contribution to the acceleration in trend productivity growth. ${ }^{13}$ The acceleration over productivity cycles would be less-perhaps half or one- or two-tenths of a percentage point.

Even if the more favorable view of the importance of ICTs is taken from the comparison between the first and second halves of the 1990s, table 2.3 suggests that the maximum acceleration due to production and use of ICTs is 0.6 of a percentage point (the MFP acceleration in the United States). Taking the contribution of ICT production to be around 0.3 of a percentage point, as calculated by Oliner and Sichel, means that the ICT use component is a maximum of 0.3 of a percentage point.

The estimate of one- or two-tenths of a percentage point from ICT use in the United States is devoid of any catch-up effects, since the United States is at the frontier. This estimate therefore indicates the extent of spillover productivity gains associated with ICT use. In Australia, they would be in addition to any catch-up effects.

The estimated magnitude fits well with other econometrically based evidence. Bean (2000) used a cross-country regression as a basis to calculate that Australia's rate of ICT uptake would have contributed 0.12 percentage points to annual productivity growth. Gretton, Gali, and Parham (2002) constructed an aggregate contribution of 0.14 percentage points from the formal analysis of firm-level data.

12. This implicitly assumes that no other contributors to productivity growth, such as technological change unrelated to ICTs, have accelerated in the United States. Using the United States as a benchmark for Australia also implicitly assumes that there are no important differences in industry composition between the two economies.

13. There has been some overstatement of the productivity acceleration apportioned to ICT production. Productivity improvements have been calculated by the dual method of measuring price declines and attributing them entirely to productivity improvements. However, some of the price declines have been due to declining profit margins (see, for example, Aizcorbe 2002). 


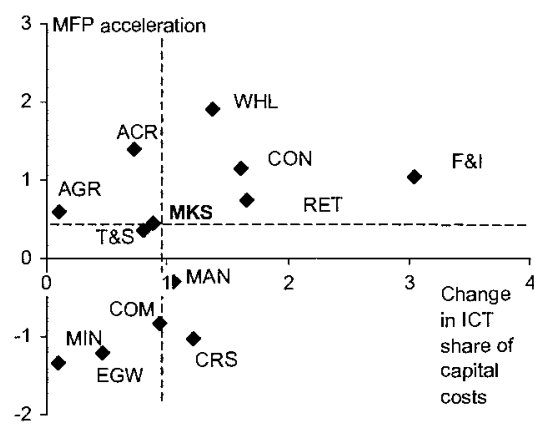

ACR Accommodation, cafes \& restaurants

AGR Agriculture

COM Communication services

CON Construction

CRS Cultural \& recreational services

EGW Electricity, gas \& water

F\&I Finance \& insurance

MAN Manufacturing

MNN Mining

MKS Market sector

RET Retail trade

T\&S Transport \& storage

WHL Wholesale trade

Fig. 2.10 Change in industry ICT use and productivity growth in Australian industries over the $1990 \mathrm{~s}$ (percentage points)

Source: Productivity Commission estimates based on unpublished ABS data.

Note: The productivity acceleration is calculated as the change in trend MFP growth between financial years 1990-95 and 1995-2000.

\subsubsection{An Industry Perspective}

While the evidence to date suggests that MFP gains associated with ICTs at the aggregate level are significant but not spectacular, there is evidence of stronger links in some industries. In some countries, including the United States, Japan, Korea, Finland, and Ireland, there are opportunities for very substantial productivity gains in the manufacture of ICTs.

There also appear to be stronger links associated with the use of ICTs in certain industries. Several studies of the United States have found evidence of productivity acceleration in the 1990s in wholesale trade; retail trade; finance, insurance, and real estate (especially in financial intermediation); and business services. These have also been characterized as intensive users of ICTs (Stiroh 2001; Nordhaus 2001; Centre for the Study of Living Standards [CSLS] 2000; Council of Economic Advisors [CEA] 2001; Pilat and Lee 2001).

As noted in section 2.2, a similar set of industries emerged in the 1990s as major contributors to Australia's productivity surge. The pattern of increased ICT usage and MFP acceleration across Australian industries is displayed in figure 2.10. ${ }^{14}$ Finance and insurance, wholesale trade, retail trade, and construction had above-average increases in ICT use and had

14. The use of trend rates of productivity growth and different periods explains the differences in industry productivity accelerations show in figures 2.4 and 2.10. 
above-average MFP accelerations. Unfortunately, the equivalent industry data are not available from BLS sources to replicate this chart for the United States.

The coincidence of industries with increases in ICT use and productivity accelerations in the United States and Australia provides some circumstantial evidence for a link between ICT use and productivity growth at an industry level-concentrated in distribution, financial intermediation, and business services (although Australian productivity data on the last industry are not available). There may also be ICT-productivity links at the firm level in other industries that, because of interfirm differences in these and other factors, do not translate as readily into industry or aggregate trends (see Brynjolfsson and Hitt 2000). But figure 2.10 also suggests that the productivity accelerations in some Australian industries were unrelated to ICT use (and equally that increases in ICT use in some industries were not associated with MFP accelerations).

The relationship between ICT use and productivity growth is complex rather than immediate and direct. ICTs are often viewed as generalpurpose technologies that require time to bring to their full potential and enable productivity gains by providing a platform for other innovations in products and processes (see, for example, Brynjolfsson and Hitt 2000 and Bresnahan, Brynjolfsson, and Hitt 2002).

The Australian evidence supports the view that it is changes in products and processes, enabled at least in part by ICTs, that generate productivity gains. ${ }^{15}$ The finance and insurance industry has been restructured to operate much more through ICTs (for example, ATM, Internet, and phone banking) than through traditional face-to-face contacts, leading to a restructuring of branch operations. Many new products (for example, financial derivatives) are now on offer.

An earlier study by Productivity Commission staff (Johnston et al. 2000) also found that ICTs played a part in the restructuring of wholesaling activities. Wholesalers were able to use bar-code and scanning technology and inventory management systems as part of the process of transforming wholesaling from a storage-based to a fast flow-through operation.

The complexity of the relationships between ICT use and productivity performance reinforces the importance of taking an industry or firm point of view. Productivity gains depend on the different actions that different firms take. A firm focus helps to identify the importance of lags between uptake of ICTs and productivity gain and the significance of complementary innovations in products and processes. The significance of ICTs and

15. If the ICT hedonic price deflators are measured correctly, advances in ICTs are measured as embodied improvements. The MFP gains associated with ICT use, for example through firm reorganization, can then be considered as disembodied improvements that are nevertheless captured by the users. In some cases, lower transactions costs in business exchanges could be a spillover benefit of expanding ICT networks. 
complementarities has been confirmed in Productivity Commission work for an international project, coordinated by the OECD, to explore the links between ICT use and performance at the firm level (Gretton, Gali, and Parham 2002). Productivity-enhancing complementarities between ICTs, skills, and business restructuring were found in an analysis of an Australian longitudinal micro data set.

The main conclusion from the aforementioned growth accounting is that the rapid uptake of ICTs has had important but comparatively small influence on aggregate productivity growth in Australia. It appears to account for, at most, one- or two-tenths of a percentage point of Australia's 1.1 percentage point MFP acceleration. On the other hand, ICTs have had more marked productivity effects in individual firms and industries. It would appear that ICTs provide at least partial explanation for the acceleration in the new set of service industries - particularly finance and insurance, construction, and wholesale trade.

However, the mere availability of new ICT technologies does not explain why Australian businesses adopted them with such vigor from the mid1980s and put them to such productive use in the 1990s. After all, Australia's prior history was generally one of relatively slow adoption of advanced technologies. And although new ICTs have been available worldwide, many other advanced countries have not been as quick or productive on the uptake. A probable explanation for this conundrum is provided later.

\subsection{Other Explanations}

The conclusion that ICTs have only contributed a relatively small part of the acceleration leaves the vast bulk of Australia's improved performance unexplained - an unsatisfactory point on which to finish this paper. This section briefly draws on other work to at least consider other possible explanations.

\subsubsection{Education and Skills}

Steve Dowrick has reminded us of the importance of skills in the workforce as a source of growth, both directly as an "embodied" labor input and indirectly in fostering absorption and further development of technology (see Dowrick 2002a,b and chap. 1 in this volume). He has highlighted the increase in school retention rates and labor force participation of females over the past ten to fifteen years. Basing his conclusions on a review of the empirical literature, Dowrick finds that raising Australia's average years of schooling by 0.8 could raise Australia's annual rate of productivity growth by a third of a percentage point through direct and indirect means.

Whereas Dowrick casts his analysis in a long-term framework (given the time required for the flow of educational attainments to affect the average across the stock of employment), it is nevertheless of considerable interest 
to see if higher skills could have played a part in Australia's 1990s productivity surge. The information presented in Dowrick's papers shows that Australia (along with New Zealand) had the highest average schooling across countries in 1960, but average attainment grew faster in comparator countries over the next four decades, so that Australia slipped significantly in position by 2000 . Nevertheless, the increase in average schooling in Australia was higher in the 1990s than in the 1980s.

Productivity Commission colleagues Barnes and Kennard (2002) have added more information. They examined preliminary ABS research that takes account of changes in workforce composition in the construction of a "quality-adjusted" labor input series. This series reflects changes in the labor inputs of groups identified by gender, educational attainment, and potential workforce experience. Taking into account workforce experience, the growth in skills was faster in the 1980s than in 1990s.

Barnes and Kennard's work suggests that there has not been a human capital accumulation effect on 1990s MFP growth. The relative increase in skills in the 1980s, accounted for the order of 0.3 of a percentage point of average annual MFP growth. But the skill contribution decelerated to around 0.05 of a percentage point from 1993-94. The direct contribution of skills to the 1990s productivity acceleration is negative on these numbers.

However, indirect effects, where education and skills assist the development and absorption of technology, could still be important. Links to the absorption of ICTs is a particular case in point, and, as noted above, complementarities between skills and ICT use have been empirically confirmed. On the other hand, there is a gap in the ability of education and skill levels to explain the broad sweep of Australia's productivity performance. When Australia's average years of schooling was above other countries around the 1960s and early 1970s, the rate of productivity catch-up was relatively poor. After a period of relatively slow growth in attainment and when Australia's average schooling had fallen below other countries, the rate of productivity catch-up was relatively high. Without undermining the general importance of education and skills, this suggests that other factors were acting as the main constraint on productivity growth in earlier decades and as the main facilitators of productivity growth in the 1990s. It is also difficult to explain the industry sources of the productivity acceleration in terms of education and skills - perhaps not so much in financial intermediation, but certainly in wholesale trade.

\subsubsection{Policy Reforms}

By the 1980s, Australia's continued slippage on the international league table of average income, combined with pessimism about the future, galvanized community support for governments to take policy action to address structural weaknesses in the Australian economy. Key objectives were to raise growth in productivity and living standards. 
Policy reforms, which have been introduced progressively since the mid1980s, have included deregulation of access to finance, floating the currency, marked reductions in barriers to trade and foreign direct investment, commercialization (and some privatization) of government business enterprises, strengthening domestic competition, and increasing labor market flexibility.

Policy reforms were designed to improve productivity performance by

- sharpening incentives to be more productive, chiefly by strengthening competition from domestic and overseas sources;

- opening the economy to trade, investment, technologies, and knowhow developed overseas;

- providing greater flexibility (for example, less regulatory restriction, more flexible labor markets) to adjust production processes and firm organization to improve productivity.

It may be a matter of logic that, if previous policy frameworks were holding productivity growth in check, reform of those frameworks would allow productivity to accelerate. But empirical evidence is needed to confirm the importance of reforms.

A number of analysts, calling on a range of empirical and other evidence, have found that microeconomic policy reforms have played a major role in Australia's productivity surge (see, for example, Productivity Commission [PC] 1999; Bean 2000; Dowrick 2000; Forsyth 2000; OECD 2001b). Macroeconomic policies have also been framed in ways that have helped to maintain stability in output growth.

However, it is difficult to put a particular order of magnitude on the influence of policy reforms on productivity growth. Formal analysis is not straightforward, particularly since it is difficult to construct a measure of policy reform at the aggregate level that accurately quantifies the timing, breadth, and intensity of reforms. By definition, reforms have operated at the micro level through a mixture of industry measures (e.g., deregulation, commercialization of government enterprises), sectoral measures (e.g., phased reductions in tariffs on manufactures) and general measures (e.g., deregulation of access to finance and the introduction of enterprise flexibility into workplace bargaining). Furthermore, it is difficult to specify a structure of lags between implementation of reforms (which was often graduated) and production response.

Despite these difficulties, Salgado (2000) found a positive link between structural reforms and aggregate productivity growth. On his estimates, reforms contributed between 0.5 and 0.9 of a percentage point at the aggregate level. Empirical support is also found in detailed industry and firm case studies (see, for example, PC 1999). For example, the links between policy reforms and strong productivity responses in government business enterprises (see section 2.2) can be firmly established. And there are evi- 
dent links between reforms and trends in proximate determinants of productivity growth, such as openness to trade and investment, industry specialization (including intra-industry trade), uptake of advanced technologies, business R\&D, and rates of innovation (PC 1999).

The influence of policy reforms can explain the developments in the Australian economy outlined in section 2.2. It can explain improvements in efficiency (MFP growth rather than capital deepening). Reforms were intended to realize catch-up gains by forcing and enabling businesses to improve technical efficiency (moving toward best practice), reduce or close inefficient operations, and adopt a more innovative, market-driven culture. Delayed success in catch-up, facilitated by policy reforms, can explain Australia's transition from an international laggard to a front-runner in productivity growth. It would also provide a "home-grown" or Australianspecific explanation for the productivity success in the 1990s.

Reforms could also help to explain the emergence of rapid and innovative use of ICTs in the 1990s. With stronger competitive incentive, businesses became more alert to the opportunities that new technologies provide and, with greater flexibility, became better able to put them to productive use.

But can the introduction of policy reforms explain the industry sources of the productivity acceleration? The incidence of reforms is clear in areas such as electricity, gas and water, and parts of communications services and transport and storage, following reforms to the operations of government enterprises. Financial intermediation has also been subject to farreaching reforms over many years. But what about the standout performer, wholesale trade?

Johnston et al. (2000) found that reforms were acting as underlying drivers and facilitators of productivity gains in wholesaling. It was not so much that wholesaling became much more ICT intensive or that new "breakthrough" technologies became available. It was more that the competitive incentives to be productive became stronger and that new flexibilities became open to businesses to use ICTs as part of a more general process of restructuring and transformation. For example, the motor vehicle industry was looking for efficiencies all along the "value chain," including in distribution, to meet the increased competition from cheaper imports entering under lower border protection. Distribution has increasingly involved streamlined delivery of imported products and more customized products from local producers building fewer models at fewer production plants. Another contributor in some areas of wholesaling was the reform of industrial relations processes that allowed greater labor flexibility through the introduction of split shifts and reduced the rigidity of job demarcations.

A plausible explanation for the productivity gains in wholesaling is that, under increased competitive pressure, businesses rationalized production 
facilities and took advantage of more efficient transport and information systems to reconfigure their distribution processes. They greatly reduced costs of storage and handling in the process. The large productivity gains in wholesaling were passed on, with profit margins declining in the 1990s (Parham et al. 2000).

\subsection{Conclusions}

Australia's labor productivity and MFP growth reached record highs in the 1990s. An acceleration of over 1 percentage point shifted Australia from being a laggard to being a front-runner on productivity growth among OECD countries. Higher labor productivity growth in the 1990s came from improved efficiency rather than capital deepening. A new set of service industries, particularly wholesale trade, construction, and finance and insurance, appears to be at the heart of the productivity acceleration.

Taking into account the historical and international trends, it seems clear that the Australian economy has embarked on a process of catch-up, much delayed in comparison with many other high-income countries. Australia has not been favored in comparison to other countries by some new technology, a change in the structure of industries, a leap forward in the skills of the workforce, or any other obvious structural factor. It seems that there has been a general improvement in efficiency of resource use that has narrowed, but not eliminated, the productivity gap with many other advanced economies. ${ }^{16}$

This paper has concentrated on the role that ICTs may have played in Australia's productivity surge. Australia is a high user but low producer of ICTs. As an importer of ICTs it has benefited from terms-of-trade effects as ICT prices have declined. Australian businesses have also used ICTs in "smart" ways - taking advantage of the product and process innovations that ICTs enable. These have been a source of productivity gain for firms. And ICTs have played a role in the service industries contributing to the acceleration in aggregate productivity.

However, the overall contribution of ICTs to higher aggregate productivity growth in terms of frontier shifts has been relatively small. Comparison with the United States suggests that use of ICTs could only account for one- or two-tenths of a percentage point of the underlying productivity acceleration. This result is lower than that found in previous U.S. and Aus-

16. A remaining productivity gap at the aggregate level is evident in the data presented in section 2.2. Research at the Groningen Growth and Development Centre on sectoral comparisons (van Ark and Timmer 2002) suggests that Australia has slipped further behind U.S. labor productivity levels in two areas of strong U.S. growth - manufacturing (where Australia remains at around 40 percent of U.S. levels) and wholesale and retail trade (around 50 percent of U.S. levels). In transport and communications, however, Australia has moved further ahead of the United States since 1980 and is now about 150 percent of the U.S. level. 
tralian studies, which have overstated the contribution of ICTs to productivity growth by failing to control for cyclical influences.

An increase in educational attainment and skills may also have contributed in some small measure to Australia's productivity surge. The timing of human capital accumulation - faster in the 1980s than the 1990sand the extent of the increase-slower in Australia than in other countries - do not sit well with Australia's historically and internationally strong productivity surge in the 1990s. There would appear to be only a weak link between skills and the industry sources of productivity growthparticularly in wholesaling.

Nevertheless, education and skills could still have some indirect influence through absorption of technology. The uptake and productive use of ICTs is a particular case in point. (The productivity impacts of skills and ICTs would therefore not be additive.)

There is theoretical and empirical support for policy reforms playing a substantial role in Australia's productivity surge through catch-up gains in efficiency. Nevertheless, further empirical evidence would help to bolster this conclusion. Policy reforms also provide plausible explanation for Australia's shift from laggard to front-runner and the industry sources of the productivity acceleration.

Rather than being "alternative" explanations, reforms ICTs and skills can be seen as complementary. In a more competitive, open, and flexible business environment, Australian businesses were forced and enabled to restructure in order to catch up. They also became more alert to opportunities that new technologies, such as ICTs, could provide, and either these businesses incorporated them into their restructuring moves or new firms emerged to take the new opportunities. That is, reforms played a part in driving the uptake of ICTs and in enabling them to be used productively. The right amount and mix of education and skills also assisted the use of ICTs and the identification and implementation of ways to take advantage of what the new technologies could offer.

\section{References}

Aizcorbe, A. 2002. Why are semiconductor prices falling so fast? Industry estimates and implications for productivity measurement. Washington, D.C.: Federal Reserve Board. Mimeograph.

Barnes, P., and S. Kennard. 2002. Skill and Australia's productivity surge. Productivity Commission Staff Research Paper. Canberra, Australia: Productivity Commission.

Bean, C. 2000. The Australian economic "miracle": A view from the north. In The Australian economy in the 1990s, ed. D. Gruen and S. Shrestha, 73-114. Sydney: Reserve Bank of Australia. 
Bresnahan, T., E. Brynjolfsson, and L. Hitt. 2002. Information technology, workplace organization, and the demand for skilled labor: Firm-level evidence. Quarterly Journal of Economics 117 (February): 339-76.

Brynjolfsson, E., and L. Hitt. 2000. Beyond computation: Information technology, organizational transformation, and business performance. Journal of Economic Perspectives 14 (4): 23-48.

Centre for the Study of Living Standards (CSLS). 2000. Trend productivity and the new economy. Paper prepared for the Economic Policy Institute. Ottawa, Canada: September.

Council of Economic Advisors (CEA). 2001. Economic report of the president. Washington, D.C.: GPO.

Dowrick, S. 2000. The resurgence of Australian productivity growth in the 1990s: Miracle or mirage? Paper presented to the 29th Annual Conference of Economists. 4 July, Queensland, Australia.

- 2002a. The contribution of innovation and education to economic growth. Paper presented at Melbourne Institute Economic and Social Outlook Conference, Towards Opportunity and Prosperity. 4-5 April, Melbourne, Australia.

- 2002b. Growth prospects for Australia: Lessons from the revolution and counter-revolution in the theory of economic growth. Paper presented at Melbourne Institute Economic and Social Outlook Conference, Towards Opportunity and Prosperity. 4-5 April, Melbourne, Australia.

Forsyth, P. 2000. Microeconomic policies and structural change. In The Australian economy in the 1990s, ed. D. Gruen and S. Shrestha, 235-67. Sydney: Reserve Bank of Australia.

Gordon, R. 2000. Does the "new economy" measure up to the great inventions of the past? Journal of Economic Perspectives 14 (4): 49-74.

Gretton, P., J. Gali, and D. Parham. 2002. Uptake and impacts of the ICTs in the Australian economy: Evidence from aggregate, sectoral, and firm levels. Paper presented at the OECD Workshop on ICT and Business Performance Conference. 9 December, Paris.

Gullickson, W., and M. Harper. 1999. Possible measurement bias in aggregate productivity growth. Monthly Labor Review 122 (2): 47-67.

Johnston, A., D. Porter, T. Cobbold, and R. Dollamore. 2000. Productivity in Australia's wholesale and retail trade. Productivity Commission Staff Research Paper. Canberra, Australia: AusInfo.

Jorgenson, D., and K. Stiroh. 2000. Raising the speed limit: US economic growth in the information age. Brookings Papers on Economic Activity, Issue no. 1:125211. Washington, D.C.: Brookings Institution.

Maddison, A. 2001. The world economy: A millennial perspective. Paris: OECD Development Center.

McGuckin, R., and B. van Ark. 2002. Performance 2001: Productivity, employment, and income in the world's economies. Conference Board Research Report no. R-1313-02-RR. New York: Conference Board.

Nordhaus, W. 2001. Productivity growth and the new economy. NBER Working Paper no. 8096. Cambridge, Mass.: National Bureau of Economic Research, January.

Organization for Economic Cooperation and Development (OECD). 2001a. The new economy: Beyond the hype. Paris: OECD.

- 2001b. OECD economic surveys: Australia. Paris: OECD. 2002. Measuring the information economy. Paris: OECD.

Oliner, S., and D. Sichel. 2000. The resurgence of growth in the late 1990s: Is information technology the story? Journal of Economic Perspectives 14 (4): 3-22. 
Parham, D. 1999. The New Economy? A New Look at Australia's Productivity Performance, Productivity Commission Staff Research Paper. Canberra, Australia: AusInfo, May.

Parham, D., P. Barnes, P. Roberts, and S. Kennett. 2000. Distribution of the economic gains of the 1990s. Productivity Commission Staff Research Paper. Canberra, Australia: AusInfo, November.

Parham, D., P. Roberts, and H. Sun. 2001. Information technology and Australia's productivity surge. Productivity Commission Staff Research Paper. Canberra, Australia: AusInfo.

Pilat, D., and F. Lee. 2001. Productivity growth in ICT-producing and ICT-using industries: A source of growth differentials in the OECD? Science, Technology, and Industry Working Paper no. 2001/4. Paris: OECD.

Productivity Commission (PC). 1999. Microeconomic reforms and Australian productivity: Exploring the links. Commission Research Paper. Canberra, Australia: AusInfo, November.

Salgado, R. 2000. Australia: Productivity growth and structural reform. In Australia: Selected issues and statistical appendix, IMF Country Staff Report 00/24, 3-35. Washington, D.C.: International Monetary Fund.

Simon, J., and S. Wardrop. 2001. Australian use of information technology and its contribution to growth. Paper prepared for the Conference of Economists. September, Perth, Australia.

Stiroh, K. 2001. Information technology and the US productivity revival: What do the industry data say? Federal Reserve Board of New York. Mimeograph.

Treasury (Commonwealth). 2002. Budget papers, statement 4: Australia's terms of trade-Stronger and less volatile. Canberra, Australia: AGPS.

van Ark, B., and M. Timmer. 2002. Industry productivity comparisons. De Economist 150 (1): 95-109.

\section{Comment Chin Hee Hahn}

This paper addresses the question why the pace of productivity growth in Australia accelerated in the 1990s. As possible explanations this paper considers three factors: micro policy reforms in various areas since the mid1980s, upgrading of labor skills, and the increasing use of ICTs. I think this is a very important question, especially in the following sense. In the growth literature, there have been debates over whether the variations in income levels or growth rates are driven by variations in total factor productivity growth (TFPG) or by variations in the pace of input accumulation. Theoretically, this debate has its root in the debates over whether the neoclassical growth theory or the endogenous growth theory is the more appropriate framework to explain the observed cross-country differences in growth rates. One of the main claims from the neoclassical side came from Mankiw, Romer, and Weil (1992), who show that, once the cross- 
country differences in human capital are taken into account, the crosscountry income levels (or growth rates) are mostly explained by the differences in input accumulation. However, there seems to be growing evidence that it is the differences in TFPG, rather than the differences in the pace of input accumulation, that drives the diverse growth outcome. Klenow and Rodriguez-Clare (1998), Easterly et al. (1993), and Rodrik (1999) are examples along this line. One of the main implications from these studies seems to be that in order to explain the variations (both cross-sectional and over time within a country) in growth rates of output, we have to look at policy or institutional factors that can explain the variations in TFPG. I think this paper asks exactly this question: what the determinants are behind Australia's productivity surge in the 1990s.

I think this paper provides very interesting facts, relying on growth accounting methodology, on the patterns of Australia's productivity growth, together with the role of ICT investments, which could be summarized as follows. First, it is carefully documented that Australia experienced acceleration in the growth rate of labor and total factor productivity in the 1990s. Second, the acceleration in the labor productivity growth is predominantly accounted for by the acceleration in the pace of TFPG, not in the pace of input accumulation. The pace of input accumulation has been clearly stable over time. Third, the acceleration in TFPG in the 1990s has been concentrated in several service-sector industries, such as wholesale trade, transport and storage, and finance and insurance, which usually use ICT intensively. Fourth, ICT capital deepening occurred while other conventional capital accumulation slowed down, making the pace of total capital accumulation stable over the decades. I think these facts provided by this paper provide the basis for any future research efforts that aim to explain the patterns of Australian productivity growth in the 1990s. If we accept these facts, then I think any serious set of explanations for the productivity surge in Australia in 1990s should be able to explain these facts altogether. I think the author is rightly going this way.

Methodologically, the author uses standard tools in the literature and pays special attention to the business-cycle effects, so that the empirical facts provided in this paper seems to be quite reliable.

Relying on the growth accounting, elimination of candidate explanations, and comparison with the benchmark case of the United States, the author claims that micro policy reforms in the 1980s account for most of the productivity surge by about 1 percentage point (annual average) in the 1990 s and that the ICT factor accounts for only a small part (at most 0.3 of a percentage point). The paper further emphasizes the importance of earlier policy reforms by claiming that increased market competition coming from the reforms induced the economic agents to use ICTs more intensively and efficiently.

Overall, the facts provided in this paper are interesting. However, al- 
though the author's emphasis on earlier policy reform as the main driving force behind the productivity surge in the 1990s is quite reasonable, I think the author's way of supporting this argument seems to be vulnerable to some criticisms, which I think substantially undermines the validity of his argument.

First, there seems to be some discrepancies between the author's initial question and what the author actually does in his paper. The question he raises is what the major factors are, among the three competing hypotheses, behind the productivity surge. However, what the author does seems to be, mainly, to answer how much of the acceleration in labor productivity growth in the 1990s is accounted for by the ICT investments. If one uses the growth accounting methodology alone, one cannot expect to distinguish between the three competing hypotheses he suggested, especially between the policy reform story and the ICT story. I think that's why the author tries to use the approach of "elimination" of a story that is relatively easily quantifiable - in this case the ICT story. However, even if we believe his argument that the ICT (and labor skill) story explains at best a small fraction of the acceleration in TFPG, that does not mean that all of the remaining TFPG surge is attributable to earlier policy reforms. That is, there may be other factors that have not been considered in the paper from the start.

Second, the paper would be more coherent if it were clear about whether the labor productivity or total factor productivity should be focused along the discussion. Since the author starts out his paper by providing facts on TFPG, I think the following discussion should be the one that tries to explain the TFPG surge, not the labor productivity surge. The growth accounting methodology he uses in his main analysis alone cannot be used to explain the TFPG surge; it is merely a methodology that further decomposes input accumulation into conventional capital and ICT capital.

Third, since the author does not deal with spillovers from ICT use, it seems to be premature to conclude that ICT is not a main factor in Australia's productivity surge. Rather, the fact that industries with rapid pickup in TFPG in the 1990s were the industries using ICT intensively suggests that the opposite might be true (although I still do not believe that this is the very plausible story). Also, the author's claim that the TFPG gain from ICT in Australia cannot exceed the gain found in the United States is not very convincing. The size of network externalities associated with ICT use might be different across countries.

So here are my suggestions. First, cross-industry variation in changes of TFPG might be worthwhile to examine. The fact that industries that experienced a productivity surge in the 1990s were mostly nontradable service industries seems to be worth paying attention to. This fact seems to imply that it might be worthwhile to look at, for example, whether there have been significant changes in terms of trade, which affected the domestic demand component of GDP disproportionately. Second, since the wholesale 
trade industry is a large industry for most economies and it experienced the most rapid acceleration in TFPG in the 1990s, it might be worthwhile to narrow down on discussing why that industry's TFPG accelerated. Third, if it is practically difficult to provide convincing evidence on the role of reforms in enhancing productivity, then it might be desirable to change the organization of the paper by strengthening the description of the empirical facts and by discussing briefly the possible reasons at the later part of the paper.

\section{References}

Easterly, William, Michael Kremer, Lant Pritchett, and Larry Summers. 1993. Good policy or good luck? Country growth performance and temporary shocks. Journal of Monetary Economics 32:459-483.

Klenow, Peter J., and Andres Rodriguez-Clare. 1998. The neoclassical revival in growth economics: Has it gone too far? In NBER macroeconomics annual 1997, ed. Ben S. Bernanke and Julio J. Rotemberg, 73-103. Cambridge: MIT Press.

Mankiw, N. Gregory, David Romer, and David N. Weil. 1992. A contribution to the empirics of economic growth. Quarterly Journal of Economics 107 (2): 407-437.

Rodrik, Dani. 1999. Where did all the growth go? External shocks, social conflict, and growth collapses. Journal of Economic Growth 4:385-412.

\section{Comment Francis T. Lui}

Dean Parham has tried to show in his paper that labor productivity has experienced a marked increase in Australia from the early 1990s to the late 1990s. Moreover, a significant portion of the increase is due to the acceleration of multifactor productivity (MFP) growth in this period. In the United States, during the same period, acceleration in MFP growth is estimated to be 0.6 percent, while that in Australia is 1 percent. The main question posed is why there is such a difference in acceleration of MFP growth rates.

The paper attributes this to a package of policy reforms in Australia. These reforms are generally aimed at enhancing competition and the flexibility for firms to make adjustments. Although economic theory tells us that they may indeed raise productivity, are we really sure that productivity acceleration in the sample period is driven by them? The paper attempts to eliminate a number of alternative possibilities. The arguments given are plausible, but they should not stop us from identifying other explanations.

First, if we look at the data cited seriously, the difference between the

Francis T. Lui is professor of economics and director of the Center for Economic Development, Hong Kong University of Science and Technology. 
United States and Australia is not very big. A difference of 0.4 percentage points per year amounts only to a total of about 2 percentage points during the entire sample period. With such a small difference, are we begging the question too much? Could this 2 percent be due to simple measurement errors? We need data from a longer sample period to rule out this possibility.

Second, the measurement of MFP growth in the United States may also be biased. Even though education has been taken into account in arriving at the MFP measures, it is unclear whether the quality aspect of education has been fully considered. It is fairly well established that the quality of U.S. schooling in the 1970s and 1980s, as measured by SAT scores and reading and mathematics skills, was declining. This means that if only the quantity side of education, such as the number of years of schooling, is taken into account, the estimate for the MFP growth in the United States will be lower than the true value.

Third, the reforms in Australia can introduce more competitive pressure in the market. This could result in MFP growth eventually, but this may take a long time to achieve. The reforms can also raise capacity utilization, which may be confused with improvement in MFP growth.

Fourth, the speeds of technology spillovers and market penetration may be different in the United States and Australia. The fact that software prices in Australia decline much faster than those in the United States indicates this possibility, which, in fact, is not an uncommon phenomenon at all. For example, as in Australia, the manufacturing sector of information and communication technology (ICT) products in Hong Kong is small. But the market penetration rate of mobile phones there is deeper than that of the United States.

Fifth, much of the acceleration is driven by wholesale trade, cafes, and restaurants. But these all exhibit negative growth in MFP in the previous period. Is the growth acceleration due to the elimination of inefficiencies in these sectors, or just recovery from business cycles? These sectors are all consumption related. Is it possible that people have revised their anticipated permanent income because of greater optimism? In this scenario, the MFP growth may not necessarily be related to the reforms.

Another contending hypothesis is that every factor contributes a little bit to the overall change in the measured MFP. The possible strong linkage between policy reforms and MFP growth may need a longer sample period to establish. Alternatively, if there were more case studies of how these reforms have affected various industries, then the conclusions in the paper would be on firmer ground. 
